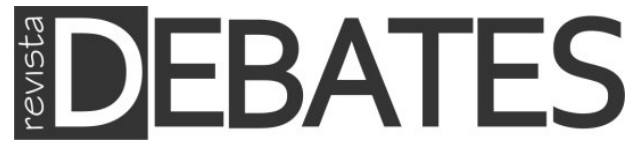

\title{
STF como ator político no Brasil: o papel do tribunal no julgamento de ações de políticas sociais entre 2003 e 2013
}

\author{
STF as a political actor in Brazil: the role of the Supreme Court in the \\ judgement of social policies between 2003 and 2013
}

\section{Lígia Mori Madeira}

\section{Resumo}

A pesquisa tem como objetivo investigar a atuação do Supremo Tribunal Federal como um ator que interfere na formulação e implementação das políticas sociais no Brasil, especialmente atuando como ator com poder de veto ou agindo como um parceiro do Executivo Federal em relação aos programas e políticas sociais. A pesquisa analisa açóes em julgamento entre os anos 2003 e 2013, verificando aspectos como a legitimidade dos atores, aplicaçóes e mérito. É possível verificar que o Judiciário brasileiro tem sido um ator de intervenção constante neste tipo de política pública, atuando principalmente nas fases de execução. No entanto, é possível prever um novo papel para o tribuna em relação à formulação de políticas públicas, no qual critérios como a definição de agenda e o desenho da intervenção passam a fazer parte das novas atribuiçóes do Poder Judiciário.

\section{Palavras-chave}

Judiciário; Judicialização da Política; Políticas Sociais; Veto ou Governança.

\section{Abstract}

The research aims to investigate the performance of the Brazilian Supreme Court as an actor who interferes in the formulation and implementation of social policies in Brazil, especially performing as veto player or acting as a partner of the Federal Executive in relation to programs and social policies. The research analyses judicial actions between 2003 and 2013, verifying aspects as legitimacy of actors, applications and substantive examination. It is possible to verify that the Brazilian judiciary has been an actor of constant intervention in this type of public policy, working mainly in the stages of implementation. However, it is possible to envision a new role for the judiciary in relation to the formulation of public policies, where criteria as the agenda-setting and the design of the intervention are part of the Judiciaries' new attributions.

\section{Keywords}

Judiciary; Judicialization of Politics; Social Policies; Veto or Governance. 


\section{Introdução}

Este trabalho busca investigar a atuação do Supremo Tribunal Federal (STF) como um ator que interfere no ciclo de políticas públicas, especialmente na fase de implementação, atuando ora como um ator de veto, ora como um parceiro do Poder Executivo Federal na promoção de políticas e programas sociais.

Em termos metodológicos, a pesquisa foi realizada a partir da análise da atuação do STF em duas situações: no julgamento de ações de controle de constitucionalidade relativas a matérias de políticas sociais, caracterizando sua atuação originária; bem como no julgamento de recursos de ações envolvendo políticas sociais de saúde, educação e assistência social, caracterizando sua atuação em sede recursal. As ações analisadas englobam os anos 2003 a 2013.

O artigo está estruturado nas seguintes seções: após essa introdução, apresentamos o referencial teórico do trabalho, iniciando pela discussão a respeito da judicialização das políticas sociais na literatura comparada, passando ao debate da judicialização e da atuação do STF no Brasil. Posteriormente apresentamos a análise da judicialização do setor de política social em questão através da literatura: saúde, educação ou assistência social, passando-se à análise da jurisprudência e seus achados. Por fim, a conclusão.

\section{Judicialização e politicas sociais na literatura comparada}

Durante a terceira onda de democratização na América Latina ampliaram-se os conflitos sociais e políticos, ao mesmo tempo em que se expandiram os direitos civis e políticos. As cortes passaram a ser o local de resolução desses conflitos, caracterizando "a judicialização da política como o processo de transferência de conflitos da esfera política ao âmbito judicial” (BASABE-SERRANO, 2012, p. 350).

Um primeiro enfoque da judicialização da política dado pela vertente institucional, que focaliza aspectos e arranjos institucionais referentes ao judiciário e sua relação com o meio político, foi dado por Tate e Vallinder (1995). Nessa teoria a judicialização pode ser entendida como, primeiro, um novo "ativismo judicial", isto é, uma nova disposiçáo de tribunais judiciais no sentido de expandir o escopo das questóes sobre as quais eles devem formar juízos jurisprudenciais (muitas dessas questôes até recentemente ficavam reservadas ao tratamento dado pelo Legislativo ou pelo Executivo), e, segundo, o interesse de políticos e autoridades administrativas em adotar procedimentos semelhantes aos do processo judicial e parâmetros jurisprudenciais em suas deliberaçôes.

Para Tate e Valinder (1995) tal processo acomete as sociedades que tenham desenvolvido as seguintes características: 
The presence of democracy, a separation of powers system, a politics of rights, a system of interest groups and a political opposition cognizant of judicial means for attaining their interests, weak parties or fragile government coalitions in majoritarian institutions leading to policy deadlock, inadequate public support, at least relative to judiciaries, and the delegation to courts of decision-making authority in certain policy areas all contribute to the judicialization of politics. It seems highly unlikely that judicialization could proceed very far in the absence of these conditions (TATE e VALLINDER, 1995, p. 33).

Após essas primeiras conceituaçôes, a literatura internacional tem se dedicado à compreensão do papel político das cortes. John Ferejohn (2002) destaca-se no desenvolvimento de análises neo-institucionais:

His work has been particularly important in developing so-called 'separation-of-powers' models of judicial behavior. These 'separation-ofpowers' models seek to explain judicial decisions by reference to exogenous constraints, such as the powers of Congress and the President to control federal courts, rather than by reference to endogenous constraints, such as the colegial nature of decision-making on certain appellate courts and the need to maintain a majority and avoid dissension (CLAYTON, 2002, p. 70).

Ferejohn (2002) apresenta três maneiras pelas quais as cortes têm assumido importantes papéis frente às legislaturas. Em primeiro lugar, os tribunais têm sido cada vez mais capazes e dispostos a limitar e regular o exercício do poder parlamentar, impondo limites materiais sobre o poder das instituiçôes legislativas. Em segundo lugar, os tribunais têm se tornado cada vez mais lugares onde a política substantiva é feita. Em terceiro lugar, os juízes têm sido cada vez mais dispostos a regular a conduta da própria atividade política - seja praticada dentro ou ao redor das legislaturas, das agências ou do eleitorado - através da construção e aplicação de normas de comportamento aceitável para os grupos de interesse, partidos políticos, eleitos e funcionários nomeados (FEREJOHN, 2002).

Segundo o autor, a judicialização não se restringe ao aumento do poder e do papel das cortes no processo de policy-making, mas também em seu uso por grupos e atores políticos, o que acaba por resultar "na transformação de questóes políticas em questôes jurídicas” (FEREJOHN, 2002, p. 42). Também é parte desse fenômeno, segundo o autor, a diminuição da capacidade das instituiçôes políticas nacionais em implementar políticas domésticas e internacionais, a partir da criação de instituições judiciais supranacionais e da incorporação de jurisprudência, especialmente de 
direitos humanos, por parte de juízes nacionais com poder para alterar as legislaçóes nacionais.

Ferejohn aponta a complexidade desses processos:

\begin{abstract}
While courts are legislating, all of us have a legitimate interest in who sits on them. While court appointments are inevitably political, they are not always partisan. When courts become politicized in a partisan sense, matters become more troubling. Democracies produce shifting majorities, and if shifts in partisan control translate into judgeships, then the content of law becomes unstable (FEREJOHN, 2002, p. 44).
\end{abstract}

Para o autor duas são as causas gerais da judicialização: uma é o aumento da fragmentaçáo do poder dentro do sistema político, limitando sua capacidade de legislar ou de ser o espaço onde as políticas são efetivamente formuladas, "quando os ramos políticos não podem agir, as pessoas que procuram resolução para os conflitos tendem a gravitar para instituições das quais elas podem obter soluções; tribunais (e processos legais associados) muitas vezes oferecem tais locais" (FEREJOHN, 2002, p. 55). A outra é um aumento na confiança das cortes como o espaço legítimo da proteção dos direitos, resultando em uma diminuição da oposição à expansão judicial, "em ambos os casos, o incentivo de uma jurisprudência que ofereceu proteção para uma ampla gama de direitos e valores humanos, e o crescimento dos tribunais capazes de dar vida a esses valores, foram em parte devido às pessoas e às suas legislaturas" (FEREJOHN, 2002, p. 56).

Segundo o autor,

When courts can make politically consequential and more-or-less final decisions, anyone with an interest in those decisions has reason to try to frame those interests in the form of persuasive legal arguments. And those interested in judicial decisions have reason to seek to influence and, if possible, to control appointments to the courts and other legal institutions. In this sense, 'judicialization' of politics tends to produce the politicization of courts. As a result, judicial decision-making tends to become politics carried on by other means (FEREJOHN, 2002, p. 63).

\title{
Direitos Econômicos e Sociais (Social and Economic Rights - SER) nas Cortes Latino-americanas
}

Outro referencial teórico essencial a essa pesquisa diz respeito ao papel das cortes em um cenário de constitucionalização de direitos e garantias econômicas e sociais (SER) e de ruptura com os ditames do Consenso de Washington no 
continente latino-americano, a que alguns autores têm-se referido ora como a New Politics of Welfare ora como a Pro-poor intervention (BRINKS e FORBATH, $2011 \mathrm{e}$ 2013; BRINKS e GAURI, 2012).

Autores como Brinks e Forbath analisam o papel das cortes e a mobilização a elas por grupos de interesses, movimentos sociais e advogados no sentido de expandir a provisão social de políticas públicas.

It is our suggestion that the politics of the welfare state in MICs are often shaped by the nature of this alliance between courts and ESR advocates. When courts take a more active role, they can become the central axis of debate, conflict, and cooperation among legislators, members of the executive, and social movements; when courts take a back seat, the debate remains more traditional, and social movements and their allies are generally weakened (BRINKS e FORBATH, 2013, p. 221).

Os autores apontam que em muitos países as cortes compensam os déficits de responsiveness e accountability por parte do Estado, e apesar de não serem uma panaceia, podem promover um debate engajando outros atores. No contexto atual vivido pelo continente de retomada no desenvolvimento e centralidade das políticas sociais, garantindo direitos que em muitos países foram constitucionalizados, as cortes constitucionais assumem dois tipos de posição, ou permanecem atuando mediante um estilo formalista de jurisprudência ou adotam um estilo mais pragmático, policy oriented:

[...] the ESR-bearing provisions of the new Latin American constitutions seem to have new salience in the corridors of state power, and a new space has opened for commerce between constitutional courts and ESR advocates, on the one hand, and technocrats in the administrative state, on the other. When and where this happens, the ESR movements seem likely to be more successful in mobilizing all the different aspects of their repertoire toward advancing what several new constitutions call the progressive realization of ESR (BRINKS e FORBATH, 2013, p. 222).

Os autores sustentam que a dificuldade inerente à realização desse tipo de direitos, somada a seu peculiar objetivo, tem produzido uma sofisticação das defesas no interior do campo legal, dos movimentos sociais, e promovido um novo estilo de litigância que é mais cooperativo e menos fechado que o tradicional estilo judicial.

Analisando o cenário constitucional brasileiro após o retorno à democracia, os autores (BRINKS e FORBATH, 2013) apontam mudanças na atuação do Judiciário. 
Segundo os autores, o Judiciário brasileiro passou a forjar uma jurisprudência dos direitos sociais constitucionais sobre a base da Constituição de 1988. Os tribunais do país, como veremos, se tornariam atores centrais na tomada de decisôes em torno de bens básicos, como os cuidados de saúde (BRINKS e FORBATH, 2013).

The Brazilian constitution was crafted a few years earlier, in 1988. Widely known as 'the citizenship constitution', it has less of the neoliberal impulse in it, but is equally founded on the hopes of various progressive groups that a robust constitution, including social and economic rights, might serve to bring Brazil's marginalized classes into full citizenship (BRINKS e FORBATH, 2013, p. 225).

A grande questáo apontada é compreender por que as cortes passam a ser esse espaço decisivo de mobilização. $\mathrm{Na}$ visão dos autores as cortes abrem espaço nas estruturas autoritárias de poder, mas principalmente, e assim caracterizam o caso brasileiro, elas cumprem um papel nas lacunas da administração estatal.

Os tribunais são chamados frequentemente em função de alguma falha ou fraqueza na administração estatal. No Brasil, grupos de pacientes usam o contencioso por tratamentos mais avançados, argumentando que o órgão encarregado de atualizar a oferta de saúde pública não está acompanhando os avanços tecnológicos da medicina. Outras vezes, eles agem para garantir o acesso a determinados medicamentos que estão fora dos previstos pela legislação e pela política nacional (BRINKS e FORBATH, 2013).

Outro fato apontado diz respeito à extensão de direitos universais a grupos excluídos ou estigmatizados:

These groups have only rarely turned to the courts, but over the past two decades, since the creation of the new constitutions, they have turned from older discourses of religious and revolutionary protest to framing their demands in the language of ESR. Even those who have not gone to court have gained a new sense of legitimate entitlement and claims on the state, in virtue of the new constitutions' inclusive promises to the poor and dispossessed and the efforts of advocates, jurists, and ESRminded state elites to realize them (BRINKS e FORBATH, 2013, p. 236).

O quadro abaixo sintetiza o estilo de decisão encontrado nas cortes latinoamericanas. 
Quadro 1 - Modelos de decisão judicial em casos de direitos sociais e econômicos

\begin{tabular}{|l|l|l|}
\hline & \multicolumn{1}{|c|}{ Diferença } & \multicolumn{1}{|c|}{ Assertiva } \\
\hline Pragmático & $\begin{array}{l}\text { Muitas decisóes brasileiras podem ser localizadas aqui, } \\
\text { mas talvez sejam mais conhecidos os casos da Corte }\end{array}$ & $\begin{array}{l}\text { Corte Constitucional de Colômbia em } \\
\text { T-760 (caso do sistema público de } \\
\text { saúde) e T-025 (caso IDP); Suprema }\end{array}$ \\
$\begin{array}{l}\text { Constitucional da África do Sul, os mais visíveis seriam } \\
\text { os casos Soobramoney (diálise) e Mazibuko (direito à } \\
\text { água/privatização) - um pouco diferente são os casos } \\
\text { Groothoom (direito à habitaçáa) e TAC } \\
\text { (Nevirapina/direito à saúde). }\end{array}$ & $\begin{array}{l}\text { Corte da Argentina no caso Viceconte } \\
\text { (Vacina para Febre Hemorrágica) e no } \\
\text { caso Mendoza (Limpeza Riachuelo). }\end{array}$ \\
\hline Silogística & $\begin{array}{l}\text { Tradicional, Corte Constitucional Chilena, mas } \\
\text { também pode ser o modelo dominante na América }\end{array}$ & $\begin{array}{l}\text { Tribunais de primeiro grau nos casos } \\
\text { de direito à saúde no Brasil; Tribunais } \\
\text { de primeiro grau nos casos de tutela } \\
\text { individual na Colômbia. }\end{array}$ \\
\hline
\end{tabular}

Fonte: Kapiszenski (2012) apud Brinks e Forbath (2013, p. 239). Tradução da autora.

Com relação à atuação das cortes no ciclo de políticas públicas, tradicionalmente sua atuação se dá nas fases de implementação, geralmente em função de demandas por accountability, no entanto, quando as cortes mostram-se mais inclinadas a efetivamente promover direitos, elas estão mais aptas a serem chamadas antes no ciclo.

When the former seems more closed and little prone to good governance, the courts are presented with more demands for both policy making and accountability. Conversely, when the courts show themselves to be more inclined to vigorous enforcement of ESR, they are more apt to be called in earlier in the policy process. At times, the judicial intervention remains at the level of improving the process and ensuring that everyone has a voice. At others, it becomes more substantive and directive. The texture of welfare state politics is the result of this complex interplay between courts, social movements, and public officials (BRINKS e FORBATH, 2013, p. 242).

O debate a respeito da judicialização em busca de direitos sociais e econômicos (SER) tem se preocupado com os possíveis ganhos com a litigância. Enquanto algumas análises mais críticas apontam a preservação das desigualdades tradicionalmente encontradas nos países latino-americanos, que subsistem no sistema judicial com seu seletivo acesso à justiça (FERRAZ, 2011a e 2011b), outras apontam efeitos simbólicos e mudanças estruturais que podem beneficiar a população em geral, 
para além dos atores devidamente representados nas cortes (BRINKS e FORBATH, 2011).

\section{Judicialização da politica e a atuação do STF no Brasil: veto ou governance?}

No Brasil, o processo de judicialização (CARVALHO e LEITÃO, 2010) tem sido compreendido como uma despolitização do processo político, pela substituição de um julgamento político de representantes eleitos por um julgamento de não eleitos (CASTRO, 1997); como uma dimensão do ativismo, que expressa o lado politizado da justiça, mas implicando na descrição do quadro institucional e das regras que permitem ou impedem açóes políticas por parte dos tribunais (ARANTES, 1999); ou como procedimentalização do direito e ampliação dos instrumentos judiciais como arena pública a propiciar a formação de opinião e o acesso do cidadão às agendas das instituições públicas (VIANNA, 1999). Mais do que a compreensão sociológica do fenômeno, interessa-nos nessa pesquisa investigar dois possíveis padrões de atuação da Suprema Corte Brasileira ${ }^{1}$ : como um ator de veto ou como um ator de governança, responsável pela execução da agenda política do Poder Executivo.

Os judiciários latino-americanos têm se caracterizado pela instabilidade e fraqueza institucional, mesmo após o retorno à democracia (KAPISZEWSKI e TAYLOR, 2008; BASABE-SERRANO, 2012). Diferentemente dessa condição, o Judiciário brasileiro tem sido visto como uma instituição independente e estável:

An independente judiciary operating under unambiguous institutional rules may have effects that are potentially as important in their policy impacts as a weak judiciary, perpetuating the power of certain groups and undercutting initiatives by other branches of government. There are of course moments when the judiciary should act as a check and balance on other branches of government (TAYLOR, 2006, p. 337).

Apesar da estabilidade, autores como Taylor apontam que em determinados momentos a estrutura das cortes pode proporcionar vantagens a determinados players políticos que buscam bloquear políticas que alterem o status quo. Nesse sentido, “o

\footnotetext{
${ }^{1}$ Com o privilegiamento desses dois padróes de atuação não pretendemos cobrir o universo de análises feitas na literatura da ciência política brasileira a respeito dos tribunais superiores e especialmente do Supremo Tribunal Federal, bem como seus temas variados de investigação, que tratam de judicialização da política (MACIEL e KOERNER, 2002; CARVALHO, 2004; DA ROS, 2008; SANTOS e DA ROS, 2008); ativismo judicial (KOERNER, 2013); formação de elites políticas (OLIVEIRA, 2011; PEGORARO, 2006).
} 
papel político do Judiciário brasileiro não pode ser subestimado. Tribunais brasileiros reverteram decisóes de presidentes poderosos, com os efeitos que reverberaram em todo o corpo político" (TAYLOR, 2006, p. 338).

Nesse cenário, muito tem se investigado a respeito das decisões tomadas por tribunais superiores, no contexto da política de revisão judicial, das relações Executivo-Judiciário e da judicialização da política latino-americana (TAYLOR, 2006). O Judiciário e seu potencial como ator de veto ${ }^{2}$ é uma das possibilidades de análise para a atuação do Judiciário brasileiro. Ele exerceria seu poder originário de veto ao interpretar a Constituição, mas na maior parte do tempo estaria absorvido por outros atores políticos de veto.

As análises sobre o Judiciário brasileiro não demonstram a presença de um ator singular com preferências uniformes, mas sim com muitos potenciais de veto, em função da existência de um sistema político com multi-vetos e das estruturas descentralizadas e federalizadas do judiciário, que permitem a paralisia de políticas públicas, decisões não uniformes e com efeitos, mesmo que temporários, e com impacto nacional.

Taylor (2006) explica esse grande uso da Suprema Corte Brasileira como um ator de veto a partir de suas características institucionais. O Judiciário federal brasileiro é uma instituição forte, empoderada pela Constituição de 1988, que reestruturou a responsabilidade das cortes, dando autonomia e independência aos juízes. $\mathrm{O}$ acesso privilegiado à suprema corte faz com que muitos atores políticos demandem decisões diretamente dela - quando o STF atua em posição originária -, mas também que as cortes inferiores produzam decisóes tidas como temporárias, sempre sujeitas à reforma pelos tribunais superiores, quando estes atuam em sede recursal, sendo o STF a última instância para a decisão de todo e qualquer caso envolvendo matéria constitucional ${ }^{3}$.

Outras características institucionais como a falta de controles hierárquicos sobre as cortes inferiores, a falta de súmula vinculante (característica não mais presente no sistema desde a Reforma do Judiciário, eis que hoje as cortes e tribunais inferiores tendem a decidir seguindo o entendimento dos tribunais superiores) e a

\footnotetext{
2 "A veto player is 'a political actor-an individual or collective-whose agreement is required to enact policy change'. Veto points are 'institutional loci for political actors to exercise vetos of legislation or policies that threaten those actors' interests or objectives'. Examples of veto points include federalism, strong bicameralism, and referenda. While the judiciary is usually not mentioned, it potentially fits the mold" (TAYLOR, 2006, p. 338).

${ }^{3}$ Aí está o motivo para esta pesquisa envolver a dupla atuação do STF, na posição originária e em sede recursal em matéria de políticas públicas sociais.
} 
atuação particularista dada pelos juízes inferiores a cada matéria, juntamente com condiçóes administrativas e fiscais favoráveis e um cenário de litigância capitaneado pelo setor público também contribuiriam para essa atuação como ator de veto do STF brasileiro.

The effects of these institutional characteristics are multiple, overlapping, and at times contradictory. In general, however, they have three important effects on policy. Because of the opportunity for highly disparate decisions and almost indefinite delay, the overall effect of the judicial process is to particularize rather than univer salize decisions. Second, given the federal government's ability to delay almost per petually and to outlast other legal entities, the current framework tends to privilege the concerns of the executive branch, no matter what decisions are taken by the lower courts. Perhaps the most important effect, however, is that judicial structure and performance motivate policy actors to access the high court in such a way as to obtain a binding and definitive decision with erga omnes effects-a decision that is largely unavailable in any lower court in the judicial hierarchy. The best and most efficient way of accomplishing this goal in Brazil is to file constitutional review cases, which allow plaintiffs to skip the lower courts and directly challenge federal government policy before the supreme federal tribunal. The breadth of the standing granted for constitutional review in Brazil is without parallel in other countries that have concentrated review (TAYLOR, 2006, p. 344).

Em um sentido oposto ao apontado pelas teorias de veto, as teorias de governança explicam o fortalecimento dos tribunais superiores como um meio para facilitar as agendas presidenciais e para evitar ameaças como o federalismo, interesses entrincheirados, coligaçôes rebeldes, e coligações de pressão. Utilizando-se dos argumentos teóricos de Whittington (2005), Nunes mostra que "um judiciário amigável aumentou os benefícios esperados de revisão judicial de presidentes brasileiros, baixando o verossimilhança de vetos judiciais contra suas saídas legislativas" (NUNES, 2010a, p. 4).

Nunes demonstra em seus estudos (2010a, 2010b) que os presidentes brasileiros na nova democracia não têm se oposto à autoridade judicial. Em vez disso, cada um deles tem defendido a expansão do poder da Suprema Corte no início de seus mandatos. Este comportamento aparentemente paradoxal é entendido pelo autor a partir do fato de que um poder judicial independente também pode servir como um mecanismo de governança. 
Segundo o autor (NUNES, 2010a), a Constituição de 1988 aumentou a autonomia das unidades subnacionais e institucionalizou um sistema de lista aberta de representação proporcional que provocou baixos níveis de disciplina interna. Esses fatores, por sua vez, criaram uma série de impedimentos a uma política eficaz de implementação, que os presidentes eleitos desde a transição tentam superar. Inesperadamente, o STF tem auxiliado presidentes a contornar algumas dessas barreiras à governança. Este resultado está sendo possível porque o Tribunal que emergiu da Constituição de 1988 é suficientemente amigável para os detentores de cargos e geralmente dá suporte a suas atividades políticas.

Nunes (2010a) utiliza o conceito de judiciário amigável para tratar de tribunais que são suficientemente moderados em suas preferências e respeitosos em sua atitude para com os outros ramos do governo. Essas duas qualidades são adquiridas através de mecanismos institucionais de controle político e compromisso. Segundo Nunes (2010a) um judiciário amigável aumenta os benefícios esperados da avaliação judicial enquanto reduz a probabilidade de vetos judiciais contra as políticas do Executivo. De acordo com ele, a revisão judicial tem minado a capacidade dos interesses arraigados para defender o status quo contra as tendências reformistas de novas maiorias, assim como quando as coligaçôes presidenciais alteram as preferências políticas dos líderes nacionais, a revisão judicial tem servido para garantir a intenção original dos redatores das políticas. Para Nunes (2010a) são os mecanismos que sujeitam o Judiciário ao controle político e à supervisão que podem desencorajar vetos judiciais para as questóes políticas mais importantes.

Assuming that courts are mechanisms of constraint at odds with the interests of elected officials, insurance theories have suggested that politicians who expect to lose elections are the main driving force behind judicial empowerment. In reaction to these claims, I have argued that judicial empowerment is often designed to improve governance, narrowly defined as incumbents' capacity to implement their policy choices. This conclusion is based on the observation that office holders in fragmented political systems can benefit from the exercise of independent judicial authority in ways not anticipated by insurance theories of reform. In Brazil, the institutional nature of the STF has allowed elected governments to rely on it to overcome barriers to policy implementation characteristic of the political system designed by the 1988 Constitution. This governance role, in turn, encouraged presidents to further empower the Court despite the fact that it also, on occasion, decides against the government. [...] This argument suggests that the expansion of judicial authority in recently constitutionalized countries hinges not on the presence of electoral 
competition per se, as insurance arguments would suggest, but on whether or not electoral winners can extract benefits from independent courts. Hegemonic presidents like Menem in Argentina may undermine the legitimacy of judicial review by violating judges' tenure protection and packing courts with partisan agents, but such outcome should not be seen as consequence of an inherent incompatibility between office holders and judicial authority. As Moustafa argues, even authoritarian regimes may benefit from an independent judiciary (NUNES, 2010a, p. 27 e 28).

É possível compreender o processo de empoderamento do STF a partir da tese de governança defendida por Nunes (2010a e 2010b), o que explicaria a estratégia do Executivo para conceder poder ao tribunal para buscar a realização de sua agenda de governo, usando o judiciário como um parceiro (ABRANCHES, 1988), rompendo assim a visão do STF como um órgão jurisdicional, engendrando o como um órgão político, dotado de uma agenda própria, relacionado a um sistema de governo (OLIVEIRA, 2013). O discurso político nacional torna-se uma construção também da atuação deste tribunal, em que perfaz sua composição e enfoque de atuação.

No estudo sobre a agenda do Superior Tribunal Federal, Olivera (2013) destaca que ao observarmos a agenda desse tribunal no governo Fernando Henrique Cardoso (1995-2002) em relação ao governo Luiz Inácio Lula da Silva (2003-2010) e de Dilma Rousseff no seu primeiro ano (2011) se pode notar uma ampliação das questóes de natureza política e social controvertidas no tribunal a partir do governo Lula.

Essa nova agenda de atuação do Supremo se mostra voltada a demandas sociais como utilização de células-tronco embrionárias (BRASIL, 2010a), o reconhecimento união de pessoas do mesmo sexo (BRASIL, 2010b), descriminalização do aborto de fetos anecéfalos (BRASIL, 2010c) a constitucionalidade das ações afirmativas (BRASIL, 2013), a constitucionalidade do Programa Universidade para Todos (PROUNI) (BRASIL, 2012), dentre outros casos. Essa peculiaridade de uma agenda pró-demandas sociais, pode-se explicar também frente a omissóes do poder legislativo em legislar sobre tais temas, seja pelo fato de serem de natureza controversa ou por desinteresse político.

A autoridade exercida pelo STF, supremocracia por Viera (2008), na deliberação sobre temas relevantes, infere-se na restruturação do sistema representativo e político. Nesse contexto, pode-se referenciar a atuação da corte, quanto às políticas adotas pelo governo, no tocante à ratificação das obrigaçóes de formulação de políticas sociais, na alteração das dinâmicas de ingresso aos serviços 
básicos de saúde, por exemplo, ou ao exercício de controle limitador do orçamento do executivo.

\section{Políticas sociais e a atuação do Judiciário brasileiro}

A Constituição Federal de 1988 restabeleceu a democracia e consagrou as bases de um complexo sistema de proteçáo social ancorado na universalidade, seguridade e cidadania (FAGNANI, 2011). Desde então, e apesar da amplitude, a política social brasileira "ainda é marcada por políticas específicas de baixa coordenação entre elas e grandes desafios em termos de abrangência (universalidade e integralidade) e qualidade dos bens e serviços oferecidos" (CASTRO, 2012, p. 1018).

Pode-se dividir as políticas sociais tendo em conta os objetivos de proteção e promoção social. No primeiro grupo encontram-se as políticas vinculadas à seguridade social; já no segundo estão as políticas voltadas a garantia de oportunidades mais amplas e equânimes de acesso aos recursos e benefícios conquistados pela sociedade em seu percurso histórico. Além dessas políticas tradicionais, desenvolvem-se as políticas de corte transversal, destacando-se as de igualdade de gênero e racial e as de etapas do ciclo de vida.

Dadas algumas características do sistema de proteção social brasileiro, especialmente a construção de grandes sistemas únicos, como os de saúde e assistência social, a distribuição de competências relacionadas ao federalismo brasileiro, com seus três entes autônomos (Municípios, Estados e a União/Governo Federal) e a tendência atual de coordenação, em que a fase de formulação das políticas fica a cargo da União, enquanto estados e municípios passam a ser os principais implementadores de políticas criadas em âmbito federal, optamos por cercear a análise nos três setores de políticas públicas que mais sofrem judicialização: saúde, educação e assistência social. Abaixo sintetizamos esse cenário.

\section{Judicialização da saúde no Brasil}

Sendo o primeiro setor de políticas sociais a se estruturar como sistema único no Brasil, em matéria de judicialização residem aqui tanto as maiores demandas quanto as principais análises. As análises que tratam da judicialização da saúde no Brasil costumam partir de juristas ou de pesquisadores da área da saúde. Os primeiros costumam realizar essa análise apontando o debate sobre previsão e restrições orçamentárias, discussóes principiológicas que enfocam proporcionalidade, mínimo existencial e reserva do possível, bem como discussóes a respeito da distribuição de competências entre os entes federativos em matéria de políticas de saúde. O debate jurídico a respeito do tema centra-se na efetividade do direito à saúde e os 
instrumentos processuais cabíveis para esse movimento (GANDINI et al., 2007); já os estudos desenvolvidos por pesquisadores da área da saúde, muitas vezes gestores em diferentes níveis da federação, costumam centrar suas análises no caráter das ações judiciais, geralmente com objeto na obtenção de medicamentos (CHIEFFI e BARATA, 2009), realizando um levantamento quanto ao mérito/necessidade de uso de determinado medicamento, quanto aos estratos e perfis sociais dos que interpóem ações judiciais, bem como do cenário do sistema de justiça nessa matéria, investigando quem são os autores das ações, que tipo de defesa/assistência jurídica tem, enfim, evidenciam os efeitos que tais decisóes tem para a formulaçáo e implementação das políticas de saúde.

Os trabalhos mais interessantes a respeito da judicialização da saúde enfocam a complexidade do tema e o embate entre duas áreas técnicas bastante diversas, bem como o impacto que tal posicionamento judicial acarreta do ponto de vista do acesso à justiça e do próprio acesso à saúde em um país desigual como o Brasil:

As implicações dessa 'juridicização constitucional' das políticas de saúde estão longe de ser triviais. De um lado, tal ‘juridicização’ impóe aos técnicos em saúde pública princípios e limites legais que antes não estavam presentes ou, quando estavam, não se revestiam da força de normas constitucionais. De outro, traz ao seio do mundo jurídico uma das mais complexas áreas de políticas públicas do Estado moderno. Não seria realista esperar que esse embate entre duas áreas técnicas distintas, que operam com conceitos e modelos de racionalidade significativamente diversos, se desse sem maiores choques e conflitos (FERRAZ e VIEIRA, 2009, p. 223).

As análises dos autores acima, especialmente as de Ferraz (2011a e 2011b) apontam criticamente a judicialização e a ruptura com uma concepção mais ampla de saúde - multidimensional - que estaria sendo substituída, no debate judicial, por uma concepção unidimensional, restrita ao atendimento à saúde, terapêutico e farmacêutico ilimitado (FERRAZ e VIEIRA, 2009).

Os autores também apontam a escassez de recursos e os gastos promovidos com a atuação do Poder Judiciário na concessão de acesso a medicamentos e tratamentos de saúde e suas consequências em relação à equidade do sistema:

A realocação judicial dos recursos da saúde não é totalmente aleatória, mas obedece muitas vezes, ainda que não deliberadamente, a uma lógica perversa de transferência de recursos dos mais necessitados aos mais privilegiados da sociedade (FERRAZ e VIEIRA, 2009, p. 243). 
Veremos na próxima seção que tipo de posicionamento o STF vem assumindo nas demandas por acesso à saúde no Brasil.

\title{
Judicialização da educação no Brasil
}

As análises a respeito da judicialização da educação no Brasil apontam a busca pela efetivação dos direitos garantidos pela Constituição Federal (CF) de 1988 (Art. 205) (BRASIL, 1988), que estabelece a educação como direito de todos e dever do Estado e da família, bem como de deveres estatais previstos no Estatuto da Criança e do Adolescente (ECA) (BRASIL, 1990) e na Lei de Diretrizes e Bases da Educação Nacional (LDB) (BRASIL, 1996).

Tem sido objeto de demandas judiciais nas cortes inferiores e nos tribunais de justiça dos estados aspectos como: "fixação de metas e prioridades; resultado final esperado; quantidade de recursos a ser investida; atendimento ou não das metas fixadas pelo próprio Poder Público; eficiência mínima na aplicação dos recursos públicos" (SILVEIRA, 2011, p. 32). Em pesquisa no estado de São Paulo, verificouse que dentre as políticas públicas educacionais as demandas por requisição de vagas na educação básica e o oferecimento de serviços que impeçam a permanência do aluno na escola foram os conflitos mais encontrados (SILVEIRA, 2011).

A autora aponta o seguinte panorama:

\begin{abstract}
[...] os últimos anos apresentaram um número maior de decisões, todavia não se trata de expansão das mesmas demandas. Com exceção das que requisitaram vagas em instituiçóes de educação infantil (ei), a maioria das açóes é levada a litígio em períodos específicos, ocasionadas por alteraçóes nas políticas de oferta do atendimento educacional e na legislaçáo (SILVEIRA, 2011, p. 37).
\end{abstract}

Pesquisas em outros estados também apontam a grande judicialização de temas relacionados à educação básica, sendo o requerimento de matriculas o maior número de ações encontradas, por exemplo, no estado de Minas Gerais (CURY e AMARAL, 2014.)

Outro tema frequente nos tribunais diz respeito ao ensino superior, conforme veremos na próxima seção, sendo as políticas afirmativas, as cotas e os programas voltados a alunos em vulnerabilidade os mais questionados no Judiciário, especialmente nos tribunais superiores. 


\section{Judicialização da assistência social no Brasil}

Em termos de judicialização, a literatura (IVO e SILVA, 2011; BICCA, 2011; SANTOS, 2009) sobre a área de assistência social tem enfocado prioritariamente nas demandas sobre o Benefício de Prestação Continuada (BPC). As açóes questionam a constitucionalidade dos critérios de acesso ao BPC a fim de garantir que o benefício seja efetivado às pessoas quando o acesso foi negado pelo Instituto Nacional da Seguridade Social (INSS), eis que sendo a elegibilidade e o acesso ao benefício garantidos a dois grupos sociais específicos, idosos e pessoas com deficiência, ao longo de sua implementação o segundo grupo tem um nível de indeferimento nas concessóes muito maior do que o primeiro.

A atuação judicial concentra-se na justiça federal, atingindo os tribunais superiores, especialmente o STF, como veremos melhor na próxima seção. Em primeiro e segundo grau as decisóes tem se concentrado no debate a respeito dos critérios de renda estabelecidos legalmente e sua incapacidade de verificação da situação de vulnerabilidade, fazendo com que o posicionamento das cortes seja de ampliação dos critérios, demonstrando um constante embate com o Instituto Nacional de Seguridade Social, que defende o critério de renda estabelecido na lei.

Os tribunais têm feito a leitura da prevalência dos princípios constitucionais, de direito à sobrevivência, à cidadania e à democracia, em uma perspectiva de acesso universal aos direitos, bem como da responsabilidade do Estado em garanti-los. Nesse sentido, a judicializaçáa dos direitos sociais apresenta-se como papel central do Judiciário. Por outro lado, as críticas a essa atuação sustentam os riscos e implicaçóes, tanto em termos políticos, mas especialmente financeiros dessas decisões:

Nesse caso, o Judiciário assumiria um papel de protagonista na implementação de políticas públicas, o que, da perspectiva desses críticos, acarretaria ainda mais problemas orçamentários e de gestão na implementação de tais políticas públicas (IVO e SILVA, 2011, p. 37).

Em matéria de decisões dos tribunais regionais, essas tem enfocado três aspectos:

Os processos indicam três tendências de correção judicial: 1. Atuação judicial em razão de erro administrativo provocado no momento da execução do BPC nas agências do INSS, 2. O questionamento legal de deficiência do BPC e 3. O questionamento do critério de pobreza estabelecido na LOAS (SANTOS, 2009, p. 73). 
Veremos, a seguir, um panorama das políticas sociais no STF.

\section{A judicialização das politicas sociais no Brasil: o caso do STF}

Conforme apresentamos acima, o STF é a mais alta instância do poder judiciário brasileiro e acumula competências típicas de uma Suprema Corte (tribunal de última instância) e de um Tribunal Constitucional (que julga questôes de constitucionalidade independentemente de litígios concretos). Sua função institucional fundamental é de servir como guardião da CF de 1988 (BRASIL, 1988), apreciando casos que envolvam lesão ou ameaça a esta última. O STF tem sua competência prevista no artigo 102 da Constituição da República Federativa do Brasil.

A tabela abaixo demonstra a atuação do tribunal ao longo das últimas décadas. É possível perceber uma certa estabilidade no número de processos distribuídos, com uma pequena queda a partir de 2008 e um menor número de processos julgados, verificando-se também uma queda e estabilidade a partir de 2009.

Gráfico 1 - Processos distribuídos e julgados no STF - 2003 a 2013

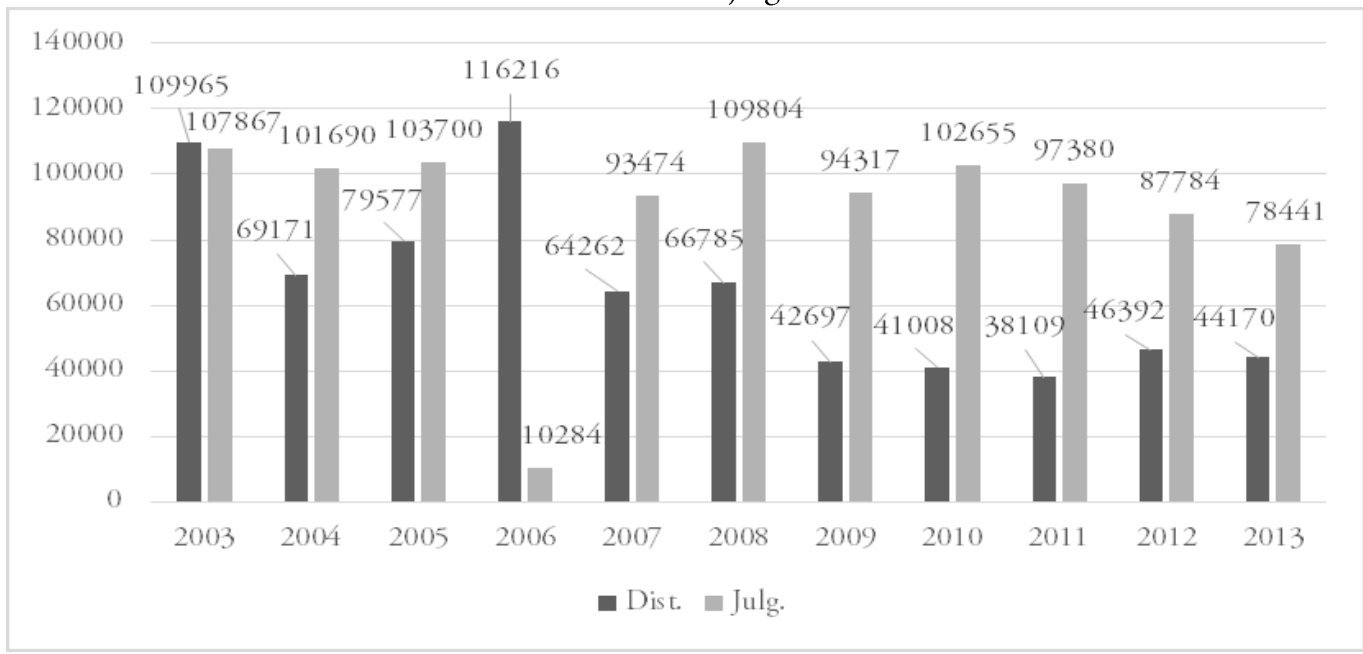

Fonte: Elaboração própria a partir de dados do STF (2014a).

Em relação à propositura de ações de controle de constitucionalidade - Ações Diretas de Inconstitucionalidade (ADIs), Ações Diretas de Constitucionalidade (ADCs), Ações Diretas de Inconstitucionalidade por Omissão (ADOs) e Arguição de Descumprimento de Preceito Fundamental (ADPFs) o panorama também é de queda, especialmente das ADIs, que são as mais preponderantes em sede de controle de constitucionalidade. Já quanto aos Recursos Extraordinários (RE) julgados o 
panorama também é de queda, especialmente a partir de 2008, quando o advento da repercussão geral resultou em uma queda vertiginosa no número de processos admitidos pelo STF.

Tabela 1 - Atuação do STF - controle de constitucionalidade e atuação recursal - 2003 a 2013

\begin{tabular}{c|c|c|c|c|c|c|c|c|c|c|c}
\hline $\begin{array}{c}\text { Classe } \\
\text { processual }\end{array}$ & $\mathbf{2 0 0 3}$ & $\mathbf{2 0 0 4}$ & $\mathbf{2 0 0 5}$ & $\mathbf{2 0 0 6}$ & $\mathbf{2 0 0 7}$ & $\mathbf{2 0 0 8}$ & $\mathbf{2 0 0 9}$ & $\mathbf{2 0 1 0}$ & $\mathbf{2 0 1 1}$ & $\mathbf{2 0 1 2}$ & $\mathbf{2 0 1 3}$ \\
\hline ADC & - & 2 & - & - & 3 & 5 & 9 & 4 & 3 & 4 & 1 \\
\hline ADI & 405 & 310 & 258 & 240 & 111 & 181 & 235 & 257 & 297 & 247 & 289 \\
\hline ADO & & & & & & & & 3 & - & 6 & 5 \\
\hline ADPF & 8 & 18 & 20 & 22 & 12 & 34 & 43 & 23 & 32 & 17 & 27 \\
\hline \multirow{2}{*}{$\mathrm{RE}$} & 43. & 35. & 39. & 45. & 49. & 40. & 25. & 24. & 20. & 13. & 11. \\
& 054 & 793 & 768 & 588 & 465 & 794 & 208 & 353 & 125 & 440 & 130 \\
\hline
\end{tabular}

Fonte: Elaboração própria a partir de dados do STF (2014a).

De modo a verificar a atuação do STF em matéria de políticas sociais, realizamos uma análise da atuação do tribunal em duas situaçóes: no julgamento de ADI relativas a matérias de políticas sociais, bem como no julgamento de recursos (RE e outros tipos de açôes) envolvendo políticas sociais de saúde, educação e assistência social, caracterizando sua atuação em sede recursal. O recorte temporal dessa investigação abrangeu os anos de 2003 a 2013. Do ponto de vista teórico investigamos o papel do Supremo como última instância hierárquica do poder judiciário e como um ator com poder de veto na esfera de interação entre os três poderes, dotado de uma agenda política própriát.

\section{Ações de controle de constitucionalidade $e$ politicas sociais no Brasil}

O controle concentrado de constitucionalidade exercido pelo STF por meio das ADIs e das ADCs foi regulamentado pela CF de 1988 que ampliou o rol de legitimados para proposição das ações, pela Lei n. 9.868 (BRASIL, 1999). A ampliação do rol de legitimados para a atuação na arena decisória do STF amplia o acesso ao poder de veto desta corte, assim, podendo articular interesses do governo e da oposição em relação às políticas do estado.

A tabela abaixo, compilada por Oliveira (2013) demonstra a atuação desses atores em um cenário ainda bastante representado pelas confederaçóes sindicais e

\footnotetext{
${ }^{4}$ Conformr o item "1.2 Judicialização da politica e a atuação do STF no Brasil: teorias explicativas e padróes de atuação" deste artigo.
} 
entidades de classes, pelos governadores, pelo Procurador Geral da República e pelos partidos políticos.

Tabela 2 - ADIs por legitimados

\begin{tabular}{c|c|c}
\hline Atores legitimados & Quantidade & \% \\
\hline Presidente da República & 8 & 0,2 \\
\hline Mesa do Senado Federal & 1 & 0,0 \\
\hline Mesa da Câmara dos Deputados & 0 & 0,0 \\
\hline $\begin{array}{c}\text { Governado de Estado ou do } \\
\text { Distrito Federal (DF) }\end{array}$ & 1.109 & 23,9 \\
\hline $\begin{array}{c}\text { Mesa da Assembleia Legislativa ou } \\
\text { Câmara Legislativa do DF }\end{array}$ & 53 & 1,1 \\
\hline Procurador-Geral da República & 947 & 20,4 \\
\hline Conselho Federal da OAB & 206 & 4,4 \\
\hline $\begin{array}{c}\text { Partido Político com } \\
\text { representaçáo no Congresso } \\
\text { Nacional }\end{array}$ & 814 & 17,5 \\
\hline $\begin{array}{c}\text { Confederaçáo Sindical ou } \\
\text { Entidade de Classe de Âmbito } \\
\text { Nacional }\end{array}$ & 1.145 & 24,6 \\
\hline Mais de 1 Legitimado* & 3 & 0,1 \\
\hline Outros Legitimados & 360 & 7,7 \\
\hline Total & 4.646 & 100 \\
\hline
\end{tabular}

* Confederação Sindical ou Entidade de Classes e Partido Político.

Fonte: Oliveira (2013, p. 26).

Em relação ao controle de constitucionalidade e aos atores legitimados para proposição, Taylor aponta que ao redesenhar o sistema judicial, a Assembleia Constituinte de 1988 criou instrumentos visando centralizar decisôes constitucionais diretamente no STF, sendo a ADI a mais utilizada. Essas açóes permitem que um seleto grupo de atores políticos possam contestar a constitucionalidade de uma lei federal ou estadual diretamente no STF (TAYLOR, 2006, p. 345).

A seleção dos julgados de controle concentrado de constitucionalidade - ADI, $\mathrm{ADC}, \mathrm{ADO}$ e $\mathrm{ADPF}$ - utilizando como palavras chave os termos "políticas públicas" e "políticas sociais" resultou em 12 processos que tratavam especificamente do tema. Restringindo a análise aos três setores definidos pela pesquisa (saúde, educação e assistência) chegamos a cinco processos. O quadro abaixo busca ilustrar esse cenário, demonstrando, por ano de propositura, autores e matéria questionada, os posicionamentos do STF em sede de constitucionalidade em matéria de políticas sociais de saúde, educação e assistência. 
Quadro 2 - Controle concentrado de constitucionalidade - ADI, ADC, ADO e ADPF

\begin{tabular}{|c|c|c|c|c|c|c|c|}
\hline Ação & $\begin{array}{c}\text { Proposi- } \\
\text { tura } \\
\text { (ano) }\end{array}$ & $\begin{array}{l}\text { Anda- } \\
\text { mento }\end{array}$ & $\begin{array}{l}\text { Julgamento } \\
\text { (ano) }\end{array}$ & Requerente & Requerido & Matéria & $\begin{array}{c}\text { Posiciona- } \\
\text { mento do } \\
\text { STF }\end{array}$ \\
\hline $\begin{array}{c}\text { ADI } \\
1698 / \\
\text { DF }\end{array}$ & 1997 & $\begin{array}{c}\text { Decisão } \\
\text { Final }\end{array}$ & 2010 & $\begin{array}{c}\text { Partido dos } \\
\text { Trabalhadores } \\
\text { (PT), Partido } \\
\text { Comunista do } \\
\text { Brasil (PCdoB) e } \\
\text { Partido } \\
\text { Democrático } \\
\text { Trabalhista } \\
\text { (PDT). }\end{array}$ & $\begin{array}{l}\text { Presidente da } \\
\text { República e } \\
\text { Ministério da } \\
\text { Educação }\end{array}$ & $\begin{array}{l}\text { ADI por omissáo } \\
\text { descumprimento do } \\
\text { arts. 6o; 23, V; 208, } \\
\text { I, 214, I - } \\
\text { Erradicaçáo } \\
\text { analfabetismo }\end{array}$ & $\begin{array}{l}\text { Improce- } \\
\text { dente }\end{array}$ \\
\hline $\begin{array}{c}\text { ADI } \\
3197 / \\
\text { RJ }\end{array}$ & 2004 & $\begin{array}{l}\text { Decisão } \\
\text { Final } \\
\text { (prejudi- } \\
\text { cada) }\end{array}$ & 2012 & $\begin{array}{c}\text { Confederação } \\
\text { Nacional dos } \\
\text { Estabelecimentos } \\
\text { de Ensino - } \\
\text { CONFENEN }\end{array}$ & $\begin{array}{l}\text { Governadora } \\
\text { do Estado do } \\
\text { Rio de } \\
\text { Janeiro e } \\
\text { Assembleia } \\
\text { Legislativa do } \\
\text { Estado do } \\
\text { Rio de } \\
\text { Janeiro }\end{array}$ & $\begin{array}{l}\text { ADI questionando lei } \\
\text { estadual que previa } \\
\text { reserva de vagas, } \\
\text { sistema de cotas para } \\
\text { negros nas } \\
\text { universidades } \\
\text { públicas estaduais do } \\
\text { Rio de Janeiro }\end{array}$ & Extinta \\
\hline $\begin{array}{c}\text { ADI } \\
3330 / \\
\text { DF }\end{array}$ & 2004 & $\begin{array}{c}\text { Decisão } \\
\text { Final }\end{array}$ & 2012 & $\begin{array}{l}\text { Confederação } \\
\text { Nacional dos } \\
\text { Estabelecimen- } \\
\text { tos de Ensino- } \\
\text { CONFENEN }\end{array}$ & $\begin{array}{l}\text { Presidente da } \\
\text { República }\end{array}$ & $\begin{array}{c}\text { Inconstitucionalidade } \\
\text { do Programa } \\
\text { Universidade para } \\
\text { Todos - PROUNI } \\
\text { (açóes afirmativas) }\end{array}$ & $\begin{array}{l}\text { Improce- } \\
\text { dente }\end{array}$ \\
\hline $\begin{array}{l}\text { ADPF } \\
186- \\
2 / \mathrm{DF}\end{array}$ & 2009 & $\begin{array}{l}\text { Decisão } \\
\text { Monocrá- } \\
\text { tica- } \\
\text { Indeferida } \\
- \text { "ad } \\
\text { referendum" }\end{array}$ & 2012 & $\begin{array}{c}\text { Democratas - } \\
\text { DEM }\end{array}$ & $\begin{array}{c}\text { Conselho de } \\
\text { Ensino, } \\
\text { Pesquisa e } \\
\text { Extensão da } \\
\text { Universidade } \\
\text { de Brasília - } \\
\text { CEPE; } \\
\text { Reitor da } \\
\text { Universidade } \\
\text { de Brasília } \\
\text { Centro de } \\
\text { Seleção e de } \\
\text { Promoção de } \\
\text { Eventos da } \\
\text { Universidade } \\
\text { de Brasília- } \\
\text { CESPE/UNB }\end{array}$ & $\begin{array}{l}\text { Programa de ação } \\
\text { afirmativa que } \\
\text { estabelece um sistema } \\
\text { de reserva de vagas, } \\
\text { com base em critério } \\
\text { étnico-racial. }\end{array}$ & $\begin{array}{c}\text { Improce- } \\
\text { dente }\end{array}$ \\
\hline $\begin{array}{c}\text { ADI } \\
4726 / \\
\text { AP }\end{array}$ & 2012 & $\begin{array}{l}\text { Aguardan- } \\
\text { do } \\
\text { Julgamento }\end{array}$ & $-\mathrm{x}-$ & $\begin{array}{l}\text { Governador do } \\
\text { Estado do } \\
\text { Amapá }\end{array}$ & $\begin{array}{l}\text { Assembleia } \\
\text { Legislativa do } \\
\text { Estado do } \\
\text { Amapá }\end{array}$ & $\begin{array}{c}\text { Programa estadual de } \\
\text { transferência de } \\
\text { renda - "Programa } \\
\text { Renda para Viver } \\
\text { Melhor" }\end{array}$ & $-x-$ \\
\hline
\end{tabular}

Fonte: STF (2014b). 
A análise da atuação do STF em sede de controle de constitucionalidade no período selecionado pela pesquisa permite inferir que, em matéria de políticas públicas, o tribunal tende a julgar garantindo a implementação destas, o que implica em garantir a governabilidade das agendas do Poder Executivo Federal quando este propóe políticas afirmativas. Não sendo objeto desse trabalho, é importante referir que o tribunal segue o mesmo padrão quando estão em jogo políticas de juventude, políticas de proteção à mulher e de prevenção às drogas. É possível sustentar a hipótese de que, na relação do STF com os poderes políticos, verifica-se uma trajetória atual marcada por um tribunal que garante governabilidade, sendo cada vez mais pró-ativo quando estão em jogo políticas públicas garantidoras de direitos sociais.

Quando estão em jogo políticas públicas propostas por entes governamentais nos estados e municípios o posicionamento do STF no julgamento das açóes de controle de constitucionalidade não é tão previsível. Se existe essa boa relação com o Poder Executivo Federal não se pode dizer o mesmo quando os conflitos se dão com outros entes subnacionais.

Apesar de a análise geral sobre a atuação da corte demonstrar uma preponderância substantiva de julgamentos em sede recursal, que analisaremos a seguir, no âmbito do controle de constitucionalidade também se verifica uma diminuição das açôes, o que poderia indicar um recuo dos atores. Análises mais aprofundadas, especialmente do teor das discussóes travadas devem revelar se em matéria de controle de constitucionalidade o STF constitui-se em uma corte garantidora de direitos econômicos e sociais (SER).

\section{Politicas sociais no Brasil: saúde, educação e assistência social e a atuação do STF em via recursal}

A investigação da atuação do STF em matéria de políticas sociais, através de pesquisa de jurisprudência entre os anos 2003 e 2013 resultou em uma pequena base de dados composta pelas seguintes áreas e número de processos judiciais:

Tabela 3 - Jurisprudência do STF: políticas sociais (2003-2013)

\begin{tabular}{c|c}
\hline Áreas de política social & Processos \\
\hline Saúde & 20 \\
\hline Educaçáo & 15 \\
\hline Assistência social & 5 \\
\hline Total & 40 \\
\hline
\end{tabular}

Fonte: Elaboração própria a partir de dados do STF (2014b). 
Os tipos de ação por setores de políticas sociais estão apresentados na tabela abaixo:

Tabela 4 - Tipos de ação judicial e setores de políticas sociais

\begin{tabular}{c|c|c|c|c}
\hline Tipos de açáo judicial & Saúde & Educaçáo & Assistência & Total \\
\hline Agravo regimental em RE & 6 & 6 & 2 & 14 \\
\hline Referendo em medida cautelar - açáo cautelar & 1 & 1 & 0 & 2 \\
\hline Agravo regimental em suspensáo de liminar & 1 & 0 & 0 & 1 \\
\hline ADI & 2 & 2 & 0 & 4 \\
\hline $\begin{array}{c}\text { Agravo regimental em suspensáo de tutela } \\
\text { antecipada }\end{array}$ & 2 & 0 & 0 & 2 \\
\hline $\begin{array}{c}\text { Questáo de ordem em ADPF } \\
\text { RE }\end{array}$ & 1 & 0 & 0 & 1 \\
\hline Agravo regimental em agravo de instrumento & 1 & 1 & 0 & 2 \\
\hline Açáo cível originária & 0 & 1 & 0 & 3 \\
\hline Tutela antecipada em açáo cível originária & 0 & 1 & 0 & 1 \\
\hline Referendo em medida cautelar em ADI & 1 & 1 & 0 & 2 \\
\hline Reclamaçáo & 0 & 0 & 3 & 3 \\
\hline Total & 18 & 13 & 5 & 36 \\
\hline
\end{tabular}

Fonte: Elaboração própria a partir de dados do STF (2014b).

\section{Ações da área da saúde}

Quanto aos casos encontrados destacam-se:

1. Agravo em Recurso Extraordinário interposto pelo Estado do RS contra decisão do Superior Tribunal de Justiça, que determinou ao Agravante a implementação de açóes com o objetivo de dotar o único hospital do Município de Cachoeirinha/RS de leitos na unidade de terapia Intensiva - UTI suficientes ao atendimento da população local.

2. Agravo regimental interposto por pessoa física contra decisão que suspendeu a execução da decisão antecipatória da tutela proferida no Agravo de Instrumento em tramitação no Tribunal de Justiça do estado de Pernambuco. Ação originária - danos morais e materiais contra o Estado de Pernambuco - tetraplegia em decorrência de assalto, responsabilização do estado pela omissão no oferecimento de segurança pública à população local, necessidade de sistema de ventilação pulmonar artificial.

3. Agravo regimental em RE interposto pelo Estado do Amazonas contra o Ministério Público do Amazonas de decisão (ação civil pública) que obriga a ampliação e melhoria no atendimento de gestantes em maternidades estaduais - dever estatal de assistência materno-infantil 
resultante de norma constitucional - obrigação jurídico-constitucional que se impóe ao poder público, inclusive aos estados-membros configuração, no caso, de típica hipótese de omissão inconstitucional imputável ao estado-membro - desrespeito à constituição provocado por inércia estatal - comportamento que transgride a autoridade da lei fundamental da república.

4. Agravo Regimental no Recurso Extraordinário. Constitucional. Direito à saúde. 1. Possibilidade de o Poder Judiciário determinar políticas públicas - açáo de cobrança interposta por associaçáo hospitalar para condenar a União ao pagamento de parcelas referentes a serviços com beneficiários do SUS.

As ações da área da saúde são as mais diversificadas e reproduzem o panorama descrito na seção anterior no que se refere à judicialização pelo acesso a medicamentos, tratamentos de saúde, ampliação de vagas e melhora da infraestrutura de atendimento do sistema de saúde, seja por parte de estados da federação, seja de municípios.

A maior atuação do STF encontra-se na fase de implementação de políticas públicas, partindo da premissa de que garantias constitucionais constrangem a atuação judicial:

O direito à saúde, expressamente previsto na CF de 1988, constitui direito subjetivo do cidadão, exigível de imediato, em oposição a omissóes do Poder Público. O legislador ordinário, ao disciplinar a matéria, impôs obrigaçôes positivas ao Estado, de modo que está compelido a cumprir o dever legal (ARE 740800/DF, Rel. Min. Cármen Lúcia, DJe 11.10.2013) (BRASIL, 2013a).

O STF discute e alega sua intervenção no ciclo de políticas públicas. Em relação à formulação ou execução considera que em princípio não cabe atuar, a menos que haja violação de preceitos constitucionais:

Em regra geral, descabe ao Judiciário imiscuir-se na formulação ou execução de programas sociais ou econômicos. Entretanto, como tudo no Estado de Direito, as políticas públicas se submetem a controle de constitucionalidade e legalidade, mormente quando o que se tem não é exatamente o exercício de uma política pública qualquer, mas a sua completa ausência insuficiente. (ARE740800/DF, Rel. Min. Cármen Lúcia, 03.10.2013) (BRASIL, 2013a). 
O Poder Judiciário, em situaçôes excepcionais, pode determinar que a Administração Pública adote medidas assecuratórias de direitos constitucionalmente reconhecidos como essenciais, sem que isso configure violação do princípio da separação de poderes. 3. Agravo regimental não provido (AI 809.018-AgR, Relator o Ministro Dias Toffoli, Primeira Turma, DJ 10.10.2012) (BRASIL, 2012a).

O direito a saúde é prerrogativa constitucional indisponível, garantido mediante a implementação de políticas públicas, impondo ao Estado a obrigação de criar condições objetivas que possibilitem o efetivo acesso a tal serviço. É possível ao Poder Judiciário determinar a implementação pelo Estado, quando inadimplente, de políticas públicas constitucionalmente previstas, sem que haja ingerência em questão que envolve o poder discricionário do Poder Executivo. Precedentes. 3. Agravo regimental improvido (AI 734.487-AgR, Rel. Min. Ellen Gracie, 20.8.2010). (BRASIL, 2010a).

Nos casos de direito à saúde, a corte entende que deve agir exigindo o cumprimento de políticas públicas já estabelecidas:

Naquele julgamento, esta Corte, ponderando os princípios do "mínimo existencial" e da "reserva do possível", decidiu que, em se tratando de direito à saúde, a intervenção judicial é possível em hipóteses como a dos autos, nas quais o Poder Judiciário não está inovando na ordem jurídica, mas apenas determinando que o Poder Executivo cumpra políticas públicas previamente estabelecidas. Agravo regimental a que se nega provimento (RE 642.536-AgR, Relator o Ministro Luiz Fux, Primeira Turma, DJe 27.2.2013) (BRASIL, 2013b).

Da mesma forma debate a legitimidade do Ministério Público para intervir na busca pela implementação de políticas públicas:

Esta Corte já firmou a orientação de que o Ministério Público detém legitimidade para requerer, em Juízo, a implementação de políticas públicas por parte do Poder Executivo, de molde a assegurar a concretização de direitos difusos, coletivos e individuais homogêneos garantidos pela CF, como é o caso do acesso à saúde (AI 809018/SCAgR, Rel. Min. Dias Toffoli, Primeira Turma, DJe 09.10.2012) (BRASIL, 2012b).

Especialmente quando o conflito envolve Estados e Municípios, na maior parte das vezes há alegação de descumprimento da separação de poderes por parte do 
judiciário, que estaria imiscuindo-se em atividade não originária, tal tese é utilizada também em várias açôes para discutir a legitimidade do Ministério Público como ator que exige a atuação estatal.

Esta Corte já firmou a orientação de que o Ministério Público detém legitimidade para em Juízo, exigir a implementação de políticas públicas por parte do Poder Executivo de molde a assegurar a concretização de direitos difusos, coletivos e individuais homogêneos garantidos pela CF, como é o caso do acesso à saúde. 2. O Poder Judiciário, em situaçóes excepcionais, pode determinar que a Administração pública adote medidas assecuratórias de direitos constitucionalmente reconhecidos como essenciais sem que isso configure violação do princípio da separação de poderes. 3. A Administração não pode invocar a cláusula da "reserva do possível" a fim de justificar a frustração de direitos previstos na Constituição da República, voltados à garantia da dignidade da pessoa humana, sob o fundamento de insuficiência orçamentária (AI 674764AgR/PI, Rel. Min, Dias Toffoli, DJe 25.10.2011) (BRASIL, 2011a).

\section{O debate explícito no STF a respeito da judicialização da saúde também} merece referência:

A tentativa do Poder Público de, no âmbito do STF, suspender decisóes judiciais é recorrente. $\mathrm{Na}$ Presidência do Tribunal existem diversos pedidos de suspensão de segurança, de suspensão de tutela antecipada e de suspensão de liminar, com vistas a suspender a execução de medidas cautelares que condenam a Fazenda Pública ao fornecimento das mais variadas prestaçôes de saúde (fornecimento de medicamentos, suplementos alimentares, órteses e próteses; criação de vagas de UTIs e leitos hospitalares; contratação de servidores de saúde; realização de cirurgias e exames; custeio de tratamento fora do domicílio, inclusive no exterior, quantidade entre de processos outros). [...] ficou constatada a judicialização do direito à saúde no Brasil. Isso porque, na maioria dos casos, a intervenção judicial não ocorre em razão de uma omissão absoluta em matéria de políticas públicas voltadas à proteção do direito à saúde, mas tendo em vista uma necessária determinaçáo judicial para o cumprimento de políticas já estabelecidas. Portanto, não se cogita do problema da interferência judicial em âmbitos de livre apreciaçáo ou de ampla discricionariedade de outros Poderes quanto à formulação de políticas públicas (AI $175 \mathrm{AgR} / \mathrm{CE}$, Rel. Min. Gilmar Mendes, Plenário, DJe 30.4.2010) (BRASIL, 2010b). 
Do ponto de vista dos atores, a análise dos casos revela um cenário em que ações movidas por particulares, pessoas físicas cujos procuradores são advogados privados ou defensores públicos costumam ter satisfeitas as suas demandas. Da mesma forma ações movidas pelo Ministério Público buscando a atuação de estados e municípios.

Em relação a essas últimas, são vários os casos em que o tribunal considera a responsabilidade solidária entre os entes da federação, chamando ao processo outros entes:

I - O STF, em sua composição plena, no julgamento da Suspensão de Segurança 3.355-AgR/RN, fixou entendimento no sentido de que a obrigação dos federados no que tange ao dever fundamental de prestaçáa de saúde é solidária (AI 808.059-AgR, Rel. Min. Ricardo Lewandowski, Primeira Turma, DJe 2.12.2010) (BRASIL, 2013c).

Em caso de pedido de medicamentos por parte de pessoas físicas também sobrevêm o mesmo entendimento do STF, de que deve haver a concessão:

O recebimento de medicamentos pelo Estado é direito fundamental, podendo o requerente pleiteá-los de qualquer um dos entes federativos, desde que demonstrada sua necessidade e a impossibilidade de custeá-los com recursos próprios. Isto por que, uma vez satisfeitos tais requisitos, o ente federativo deve se pautar no espírito de solidariedade para conferir efetividade ao direito garantido pela Constituição, e nấo criar entraves jurídicos para postergar a devida prestação jurisdicional (RE 607.381AgR, Rel. Min. Luiz Fux, Primeira Turma, DJe 17.6.2011). (BRASIL, 2011b).

Em caso de ações movidas por associações hospitalares, entidades privadas, contra os entes da federaçáo tem havido a condenação destes:

A instituição privada não pode ser punida por atender aqueles que procuram o atendimento pelo SUS. Se os limites foram ultrapassados, foram-no em cumprimento da referida Portaria e em benefício da sociedade e não da Associação de Caridade Santa Casa do Rio Grande, a qual não pode ser responsabilizada pelos custos da prestação de um serviço que incumbe ao Estado financiar (RE 1.211.668/RS, Rel. Min. Eliana Calmon, STJ, DJe 18.12.2013). (BRASIL, 2013d). 
Abaixo sintetizamos as configuraçóes de partes encontradas nos processos analisados:

Quadro 3 - Atores nas açóes de saúde no STF

\begin{tabular}{|c|}
\hline SAÚDE \\
\hline Estado (federação) x MP \\
\hline Estado (federação) x União \\
\hline Estado (federação) x pessoa física \\
\hline Partido político x Governador de estado e Assembleia Legislativa \\
\hline Associação x União, MPF e Associação \\
\hline Associaçáo x Presidente da República e Congresso Nacional \\
\hline Uniáo x Associaçáo hospitalar \\
\hline União x pessoa física \\
\hline União x MPF, Estado (federação) e município \\
\hline
\end{tabular}

Fonte: Elaboração própria a partir de dados do STF (2014b).

As ações em sede recursal da área da saúde reproduzem os achados da literatura, em termos de mobilização da corte por direitos econômicos e sociais (SER), da construção de uma jurisprudência de direitos sociais no Brasil e de um estilo policy oriented do tribunal. Em relação à prevalência do tribunal como um ator de veto ou de governança, as açóes desse setor de política social não revelam nem um nem outro padrão, dado que estão em jogo a implementação de políticas e direitos já existentes, muito mais do que a constituição de uma nova agenda ou de novas políticas em formulação.

\section{Ações da área da educação}

As ações encontradas debatem prioritariamente os seguintes temas:

1. Políticas afirmativas para ingresso na Universidade pública.

2. Exigência de atendimento em creche e pré-escola por parte de município, concedendo matrículas para crianças até cinco anos de idade.

Conforme vimos na seção anterior, o debate sobre judicialização da educação no Brasil costuma centrar-se nesses dois aspectos, enfocando ora a constitucionalidade das ações afirmativas e políticas de cotas, ora exigindo o cumprimento de direitos constitucionalmente estabelecidos, como o direito à educação.

O posicionamento da corte em relação a ações afirmativas merece destaque: 
Não há outro modo de concretizar o valor constitucional da igualdade senão pelo decidido combate aos fatores reais de desigualdade. O desvalor da desigualdade a proceder e justificar a imposição do valor da igualdade. A imperiosa luta contra as relaçóes desigualitárias muito raro se dá pela via do descenso ou do rebaixamento puro e simples dos sujeitos favorecidos. Geralmente se verifica é pela ascensão das pessoas até então sob a hegemonia de outras. Que para tal viagem de verticalidade são compensadas com esse ou aquele fator de supremacia formal. Não é toda superioridade juridicamente conferida que implica negaçáo ao princípio da igualdade (ADI 3.330, Rel. Min. Ayres Britto, julgamento em 3-52012, Plenário, DJE de 22-3-2013). (BRASIL, 2012c).

Em relação à segunda matéria, reproduzem-se os argumentos quanto à necessidade de atuação judicial em matéria de execução de políticas públicas constitucionalizadas, sempre que o Poder Executivo mostrar-se omisso:

Embora inquestionável que resida, primariamente, nos Poderes Legislativo e Executivo, a prerrogativa de formular e executar políticas públicas, revela-se possível, no entanto, ao Poder Judiciário, ainda que em bases excepcionais, determinar, especialmente nas hipóteses de políticas públicas definidas pela própria Constituição, sejam estas implementadas, sempre que os órgãos estatais competentes, por descumprirem os encargos político-jurídicos que sobre eles incidem em caráter impositivo, vierem a comprometer, com a sua omissão, a eficácia e a integridade de direitos sociais e culturais impregnados de estatura constitucional. DESCUMPRIMENTO DE POLÍTICAS PÚBLICAS DEFINIDAS EM SEDE CONSTITUCIONAL: HIPÓTESE LEGITIMADORA DE INTERVENÇÃO JURISDICIONAL. A intervenção do Poder Judiciário, em tema de implementação de políticas governamentais previstas e determinadas no texto constitucional, notadamente na área da educaçáo infantil (RTJ 199/1219-1220), objetiva neutralizar os efeitos lesivos e perversos, que, provocados pela omissão estatal, nada mais traduzem senão inaceitável insulto a direitos básicos que a própria Constituição da República assegura à generalidade das pessoas (ARE 639337 AgR, Rel. Min. Celso de Mello, Segunda Turma, julgado em 23/08/2011) (BRASIL, 2011c).

Prevalece nesse tipo de julgamento a tese do mínimo existencial, composto por uma série de prestaçóes que precisam ser garantidas pelo Estado: 
A noção de "mínimo existencial", que resulta, por implicitude, de determinados preceitos constitucionais (CF, art. $1^{\circ}$, III, e art. $3^{\circ}$, III), compreende um complexo de prerrogativas cuja concretização revela-se capaz de garantir condiçóes adequadas de existência digna, em ordem a assegurar, à pessoa, acesso efetivo ao direito geral de liberdade e, também, a prestaçóes positivas originárias do Estado, viabilizadoras da plena fruição de direitos sociais básicos, tais como o direito à educação, o direito à proteção integral da criança e do adolescente, o direito à saúde, o direito à assistência social, o direito à moradia, o direito à alimentação $\mathrm{e}$ o direito à segurança (ONU, 1948, Artigo XXV).

Assim como na saúde, quando o tema é acesso à educação, costuma haver uma flexibilização dos critérios orçamentários e de financiamento da política, não prevalecendo as teses de reserva do possível:

A cláusula da reserva do possível - que não pode ser invocada, pelo Poder Público, com o propósito de fraudar, de frustrar e de inviabilizar a implementação de políticas públicas definidas na própria Constituição encontra insuperável limitação na garantia constitucional do mínimo existencial, que representa, no contexto de nosso ordenamento positivo, emanação direta do postulado da essencial dignidade da pessoa humana (ARE 639337 AgR, Rel. Min. Celso de Mello, Segunda Turma, julgado em 23/08/2011) (BRASIL, 2011c).

Em relação aos atores, verifica-se a prevalência de açóes movidas pelo Ministério Público contra estados e municípios e nesses casos, sempre que o conflito envolve a exigência de prestação de serviços sociais o STF tende à condenação, atuando na exigência da execução de políticas públicas. Por outro lado, quando está em jogo alguma agenda federal, como políticas afirmativas, tende a prevalecer a agenda, com o STF dando ganho de causa ao governo ou à entidade que está implementando tal política.

$\mathrm{O}$ quadro abaixo demonstra todas as configuraçóes de atores encontradas nas ações. 
Quadro 4 - Atores nas açóes de educação no STF

\begin{tabular}{|c|}
\hline EDUCAÇÃO \\
\hline Município x pessoa física \\
\hline Estado (federação) x MP \\
\hline Estado (federação) x União \\
\hline Município x MP \\
\hline MPF x MP estadual \\
\hline Governador e Assembleia Legislativa Estadual x Universidade \\
\hline Partido Político x Presidente da República e ministros de Estado \\
\hline Pessoa física x Universidade \\
\hline
\end{tabular}

Fonte: Elaboração própria a partir de dados do STF (2014b).

As ações em sede recursal da área da educação demonstram a prevalência do tribunal como um ator de governança, especialmente quando se trata de açóes afirmativas que são pauta prioritária do Governo Federal e recebem a tentativa de veto por parte de inúmeros atores políticos e da sociedade civil. Em relação à judicialização por direito à educação, verificamos novamente a construção de uma jurisprudência de direitos sociais e de um estilo policy oriented do tribunal, que exige a implementação de políticas e direitos já garantidos em lei.

\section{Ações da área da educação}

As ações da área de assistência social concentram-se em dois programas:

1. Programa Bolsa Família - açôes de particulares, pessoas físicas contra a União e municípios, buscando o acesso ao benefício e questionando os critérios de elegibilidade das famílias ao programa.

2. Benefício de Prestação Continuada - ações de particulares, pessoas físicas buscando o acesso ao benefício e questionando os critérios de elegibilidade, especialmente para deficientes físicos.

Em relação à primeira matéria, não chega a haver decisão de mérito, com o STF apenas manifestando-se em relação à admissibilidade ou não do recurso.

Em relação ao BPC, reproduzindo os achados da literatura, encontra-se o maior número de decisóes e um debate mais desenvolvido. Aqui nessas reclamações, contrariando a tese da governança e o posicionamento de órgãos do Poder Executivo Federal como o INSS, verifica-se uma atuação do STF como ator de veto, ao ampliar o entendimento restritivo dado pela lei na hora de implementar políticas sociais para determinados grupos sociais. Verifica-se também, da análise desses julgados, uma mudança de posicionamento na corte, que de um viés mais legalista, passa a um viés mais extensivo na interpretação legal e constitucional. 
O caso concreto subjacente aos autos traduz um problema que é de todos nós conhecido. Há alguns anos temos recebido impressionante quantidade de processos, em sua maioria recursos extraordinários e reclamaçôes, cujo tema principal é a concessão judicial do benefício assistencial previsto no art. 203, inciso V, da Constituição de 1988. Uma difícil questâo constitucional, que vem sendo resolvida pela atuação corajosa da magistratura de primeira instância, na tentativa de remediar um gravíssimo problema social que se notabiliza como uma soma de injustiças, decorrente de uma desencontrada relação entre a letra objetiva da lei e a vontade da Constituição. O exame dos diversos casos revela um comportamento judicial peculiar, porém muito comum. A análise histórica dos modos de raciocínio judiciário demonstra que os juízes, quando se deparam com uma situação de incompatibilidade entre o que prescreve a lei e o que se lhes apresenta como a solução mais justa para o caso, não tergiversam na procura das melhores técnicas hermenêuticas para reconstruir os sentidos possíveis do texto legal e viabilizar a adoção da justa solução (RE 580963/PR, Plenário, Rel. Min. Gilmar Mendes, 18.04.2013) (BRASIL, 2013e).

Esse é o tom da recente história da concessão judicial do benefício assistencial, que vale a pena retomar em uma rápida análise descritiva. A Lei $\mathrm{n}^{\circ}$ 8.742, de 7 de dezembro de 1993, a Lei de Organização da Assistência Social - LOAS (BRASIL, 1993), ao regulamentar o art. 203, inciso V, da Constituição da República, estabeleceu os critérios para que o benefício mensal de um salário mínimo seja concedido aos portadores de deficiência e aos idosos que comprovem não possuir meios de prover a própria manutenção ou de tê-la provida por sua família.

Apesar das concessôes e da declaração de inconstitucionalidade da lei que considera apenas critérios econômicos na hora da concessão do benefício, a corte preocupou-se com as consequências econômicas de tal decisão, não declarando a nulidade da lei de modo a permitir que o Estado tenha condições de organizar seu orçamento.

Em matéria de atores, prevalecem nas políticas de assistência social as demandas de particulares em relação a entes federados, da União como formuladora e financiadora da política e os municípios como implementadores.

Abaixo os atores dessas ações: 
Quadro 5 - Atores nas açóes de assistência social no STF

\begin{tabular}{|c|}
\hline ASSISTENNCIA \\
\hline Pessoa física x União \\
\hline INSS x pessoa física \\
\hline Pessoa física x União e municípios \\
\hline
\end{tabular}

Fonte: Elaboração própria a partir de dados do STF (2014b).

Acreditávamos que as ações em sede recursal da área de assistência social apresentariam um panorama mais rico, dada a prevalência de uma série de programas e políticas em curso, como o Programa Bolsa Família, o Plano Brasil Sem Miséria, mas dado o público em situação de vulnerabilidade, provavelmente as dificuldades de acesso à justiça impedem que tal setor tenha um cenário mais judicializado, especialmente em se tratando do STF. Também acreditávamos que em matéria de controle de constitucionalidade haveria um panorama de tentativa de bloqueio dessas políticas por parte de atores políticos de oposição, que buscariam a corte como um ator de veto, o que não foi encontrado. Mas percebemos novamente a corte como um espaço de mobilização por direitos econômicos e sociais (SER), com um estilo policy oriented.

Para além desse debate, cabe apresentar os julgados com repercussão geral ${ }^{5}$ que tratam dos temas de políticas públicas e de políticas sociais:

5 A preliminar formal de repercussão geral é exigida nos recursos extraordinários interpostos de acórdãos publicados a partir de 3 de maio de 2007, data da entrada em vigor da Emenda Regimental no 21/07 ao RISTF, que estabeleceu as normas necessárias à execução das disposiçóes legais e constitucionais sobre o novo instituto (BRASIL, 2007). 
Quadro 6 - Matérias dos Julgamentos

\begin{tabular}{|c|c|}
\hline Matéria & Açöes \\
\hline $\begin{array}{l}\text { Sistema de reserva de vagas, como forma de ação afirmativa de inclusão social, } \\
\text { estabelecido por universidade. }\end{array}$ & $\begin{array}{l}\text { RE } 597285 \\
\text { Manifestação } \\
\text { Acórdão }\end{array}$ \\
\hline Bloqueio de verbas públicas para garantia de fornecimento de medicamentos. & $\begin{array}{c}\text { RE } 607582 \\
\text { Manifestação }\end{array}$ \\
\hline $\begin{array}{l}\text { Auto-aplicabilidade da imunidade relativa à contribuiçáo sobre os proventos de } \\
\text { aposentadorias e pensões dos servidores públicos, prevista no art. } 40, \$ 21 \text {, da CF, } \\
\text { quando o beneficiário for portador de doença incapacitante. }\end{array}$ & $\begin{array}{l}\text { RE } 630137 \\
\text { Manifestação }\end{array}$ \\
\hline $\begin{array}{l}\text { Dever estatal de assegurar o atendimento em creche e pré-escola às crianças de zero a } 5 \\
\text { (cinco) anos de idade. }\end{array}$ & $\begin{array}{l}\text { AI } 761908 \\
\text { Manifestaçáo }\end{array}$ \\
\hline $\begin{array}{l}\text { Acumulação da aposentadoria por invalidez com o benefício suplementar, previsto no } \\
\text { art. } 9^{\circ} \text { da Lei } 6.367 / 76 \text {, incorporado pela normatização do atual auxílio-acidente, a teor } \\
\text { do que dispunha o art. } 86 \text { da Lei } 8.213 / 91 \text {, na sua redaçáo primitiva. }\end{array}$ & $\begin{array}{l}\text { RE } 687813 \\
\text { Manifestação }\end{array}$ \\
\hline $\begin{array}{c}\text { Limites do Poder Judiciário para determinar obrigaçóes de fazer ao Estado, consistentes } \\
\text { na realizaçáo de concursos públicos, contratação de servidores e execuçáo de obras que } \\
\text { atendam o direito social da saúde, ao qual a Constituição da República garante especial } \\
\text { proteção. }\end{array}$ & $\begin{array}{l}\text { RE } 684612 \\
\text { Manifestaçáo }\end{array}$ \\
\hline $\begin{array}{l}\text { Legitimidade do Ministério Público para ajuizar açáo civil pública que tem por objetivo } \\
\text { compelir entes federados a entregar medicamentos a portadores de certas doenças. }\end{array}$ & $\begin{array}{l}\text { RE } 605533 \\
\text { Manifestação }\end{array}$ \\
\hline
\end{tabular}

Fonte: Elaboração própria a partir de dados do STF (2014b).

Nesses casos verifica-se novamente um posicionamento pró-políticas sociais por parte do STF, que ao considerar a repercussão geral dessas matérias entendeu a importância da deliberação judicial sobre esses assuntos, novamente compreendendo ser central seu papel como fiscalizador da execução dessas políticas e desses direitos.

\section{Conclusões}

Este artigo foi produzido como estudo exploratório de uma pesquisa mais ampla que busca realizar uma análise do cenário judicial em matéria de políticas públicas sociais no Brasil, lançando um olhar sobre o fenômeno em curso nos tribunais superiores para enfim mapear as causas e açóes nos tribunais regionais do país. A pesquisa mais ampla buscará a construção de tipologias de ações, assim como a análise dos padrões de atuação das instituições públicas no sistema de justiça (não apenas o Judiciário, mas também o Ministério Público e a Defensoria Pública), 
investigando, através da análise de conteúdo das decisões, se há padrões homogêneos de atuaçáo nas diferentes causas objeto de análise, tendo em conta os constrangimentos institucionais, os padrôes de recrutamento e a literatura referência da área.

A análise está em curso e esta publicação é resultado deste trabalho preliminar, em que investigamos o papel do STF no julgamento de ações envolvendo políticas sociais no Brasil, analisamos a atuação da corte como Tribunal Constitucional e como Suprema Corte durante os anos 2003 e 2013.

Sabe-se que o STF tem desempenhado um papel central no Brasil no contexto de judicialização em busca de direitos sociais e econômicos (SER), fenômeno bastante conhecido nos países desenvolvidos e que vem tomando vulto no continente latino-americano especialmente na última década, a partir da retomada do debate sobre desenvolvimento e da centralidade das políticas sociais e da constitucionalização de direitos nas novas democracias. A partir dessa análise preliminar é possível lançar alguns questionamentos que serão devidamente investigados em profundidade, mas que ficam como pistas desse processo em curso no Brasil:

1. Em primeiro lugar é importante o papel do Judiciário e do STF no ciclo de políticas públicas. Ao longo da trajetória do tribunal pode-se verificar distintas fases: a) uma atuação tímida, respeitando a separação de poderes; b) uma atuação como fiscal da implementação de políticas públicas, dada a omissão ou o descumprimento das exigências legais por parte dos poderes públicos; c) uma atuação mais recente, ainda incipiente, nas primeiras fases das políticas públicas, verificando-se um papel na constituição da agenda ou mesmo na formulação de políticas públicas. A partir dessa constatação é possível sustentar que quanto mais as cortes mostram-se inclinadas a efetivamente promover direitos, mais elas estão aptas a ser chamadas e atuarem antes no ciclo de políticas públicas?

2. No que diz respeito à relação do STF com os poderes políticos verifica-se uma trajetória marcada por dois momentos, que pode ser compreendida a partir de duas teorias da ciência política contemporânea: após a CF/88 (BRASIL, 1988) o STF teve uma atuação marcada pela parcimônia, sendo utilizado como ator de veto por parte de vários entes políticos que promoviam ações de controle de constitucionalidade com vistas a protelar as agendas governamentais. Num segundo momento que se estende de meados dos anos 1990, mas cujas características são mais bem encontradas na última década, 
de um tribunal de veto passa-se a um tribunal que garante governabilidade, sendo cada vez mais proativo quando estão em jogo políticas públicas garantidoras de direitos sociais. A partir desse cenário, seria possível sustentar que os padrôes de atuação da corte dependem do projeto político em curso, especialmente no Poder Executivo Federal? É a configuração mais recente de ministros que sustenta essa atuaçáo? Que outros elementos influenciam nos posicionamentos do tribunal? Em um cenário de agenda mais restritiva em matéria de direitos sociais o tribunal voltaria a atuar como um ator de veto?

3. Se existe essa boa relação com o Poder Executivo Federal não se pode dizer o mesmo quando os conflitos se dáo com outros entes subnacionais. A análise demonstra que o STF costuma exercer seu papel como fiscalizador e mandatário do cumprimento de políticas públicas por parte de estados e municípios. Por que há essa diferença de atuação? Novamente é o ciclo de políticas públicas que interfere nos padróes de julgamento, uma vez que as açôes envolvendo os entes subnacionais revelam a preponderância das fases de implementação?

4. Como tribunal constitucional, verifica-se uma diminuição na distribuição das açôes ao longo da última década, o que poderia indicar um recuo dos atores. Seria o comportamento pró-políticas sociais a explicação para essa diminuição na judicialização?

Por fim, novos estudos buscando correlacionar variáveis como a configuração da corte, a trajetória sócio-profissional dos ministros, seus padróes de recrutamento, o perfil da presidência e os comportamentos em diferentes períodos de tempo podem ser profícuos para elucidar melhor a relação do STF com as políticas sociais no Brasil.

- Lígia Mori Madeira é Professora do Departamento, do Programa de Pós-Graduação em Ciência Política e do Programa de PósGraduação em Politicas Públicas da Universidade Federal do Rio Grande do Sul (UFRGS), e Pesquisadora do Núcleo de Pesquisa Justiça e Poder Político da UFRGS. Doutora em Sociologia pela UFRGS. E-mail: ligiamorimadeira@gmail.com. 


\section{Referências}

ABRANCHES, Sérgio. Presidencialismo de coalizão: o dilema institucional brasileiro. Dados, Rio de Janeiro, v. 31, n. 1, p. 3-55, 1988.

ARANTES, Rogério. Direito e política: o Ministério Público e a defesa dos direitos coletivos. RBCS, São Paulo, v. 14, n. 30, p. 83-102, fev. 1999.

BASABE-SERRANO, Santiago. Presidential Power and the Judicialization of Politics as Determinants of Institutional Change in the Judiciary: The Supreme Court of Ecuador (1979-2009). Politics \& Policy, Mexico City, v. 40, n. 2, p. 339-361, abr. 2012.

BICCA, Carolina Scherer. O "Ativismo Judicial" no controle das Politicas Fúblicas: o caso da Assisténcia Social no Brasil. 2011. 171f. Dissertação (Mestrado em Direito Constitucional) - Programa de Pós Graduação em Direito Constitucional, Instituto Brasiliense de Direito Público, Brasília, 2011.

BRASIL. Supremo Tribunal Federal. Recurso Extraordinário com Agravo. n. 740800/DF. Ministra Cármen Lúcia, Brasília 03 out. 2013, Diário de Justiça Eletrônico, 2013a

BRASIL. Supremo Tribunal Federal. Recurso Extraordinário. n. 642.536-AgR. Ministro Luiz Fux, Brasília 27 fev. 2013, Diário de Justiça Eletrônico, 2013b.

BRASIL. Supremo Tribunal Federal. Arguição de Descumprimento de Preceito Fundamental. n. 1862/DF. Ricardo Lewandowski, Brasília 31 jul. 2013, Diário de Justiça, 2013 c.

BRASIL. Supremo Tribunal Justiça. Recurso Especial. RE n. 1.211.668/RS, Rel. Min. Eliana Calmon, Rio Grande do Sul 18 fev. 2013, Diário de Justiça Eletrônico, 2013d.

BRASIL. Supremo Tribunal Federal. Recurso Extraordinário. RE n. 580963/PR. Ministro Gilmar Mendes, Paraná 18 abr. 2013, Diário de Justiça Eletrônico, 2013e.

BRASIL. Supremo Tribunal Federal. Agravo de Instrumento. n. 809.018-AgR. Ministro Dias Toffoli, Brasília 10 out. 2012, Diário de Justiça Eletrônico, 2012a.

BRASIL. Supremo Tribunal Federal. Agravo de Instrumento. n. 809018/SC-AgR. Ministro Dias Toffoli, Santa Catarina 09 out. 2012, Diário de Justiça Eletrônico, 2012b.

BRASIL. Supremo Tribunal Federal. Ação Direita de Inconstitucionalidade. n. 3.330/DF. Ayres Britto, Brasília 03 maios 2012, Diário de Justiça, 2012c.

BRASIL. Supremo Tribunal Federal. Agravo de Instrumento. n. 674764-AgR/PI. Ministro Dias Toffoli, Piauí 25 out. 2011, Diário de Justiça Eletrônico, 2011 a.

BRASIL. Supremo Tribunal Federal. Recurso Extraordinário. n. 607.381-AgR. Ministro Luiz Fux, Brasília 17 jun. 2011, Diário de Justiça Eletrônico, 2011 b.

BRASIL. Supremo Tribunal Federal. Recurso Extraordinário com Agravo. n. 639337-AgR. Ministro Celso de Mello, Brasília 23 ago. 2011, Diário de Justiça, 2011c.

BRASIL. Supremo Tribunal Federal. Agravo de Instrumento. n. 734.487-AgR. Ministra Ellen Gracie, Brasília 20 ago. 2010, Diário de Justiça Eletrônico, 2010a.

BRASIL. Supremo Tribunal Federal. Agravo de Instrumento. n. 175-AgR/CE. Ministro Gilmar Mendes, Ceará 30 abr. 2010, Diário de Justiça Eletrônico, 2010b.

BRASIL. Supremo Tribunal Federal. Agravo de Instrumento. n. 808.059-AgR. Ministro Ricardo Lewandowski, Brasília 02 dez. 2010, Diário de Justiça Eletrônico, 2010c.

BRASIL. Vigência. Supremo Tribunal Federal. 2007. Disponível em: <http://www.stf.jus.br/portal/cms/verTexto.asp?servico=jurisprudenciaRepercussaoGeral\&pagina= vigencia>. Acesso em: 20 jul. 2014.

BRASIL. Senado Federal. Lei de Diretrizes e Bases da Educação Nacional: n. 9394/96. Brasília: 1996. 
BRASIL. Lei no 8069, de 13 de julho de 1990. Estatuto da criança e do adolescente (ECA). Brasília: Ministério da Saúde, 1991.

BRASIL. Constituição. Constituição da República Federativa do Brasil de 1988. Brasília, 1988.

BRINKS, Daniel M; GAURI, Varun. The Law's Majestic Equality? The Distributive Impact of Litigating Social and Economic Rights. (Policy Research Working Paper 5999). Washington DC: The World Bank, Development Research Group, Human Development and Public Services Team, 2012.

BRINKS, Daniel M.; FORBATH, William. The Role of Courts and Constitutions in the New Politics of Welfare in Latin America. In: PEERENBOOM, Randall; GINSBURG, Tom (Eds.). Law and Development of Middle Income Countries. New York: Cambridge University Press, 2013. p. 221-245.

. Commentary: Social and Economic Rights in Latin America - Constitutional Courts and the Prospects for Pro-poor Interventions. Texas Law Review, Austin, EUA, v. 89, p. 1943-1955, 2011.

CARVALHO, Ernani; LEITÃO, Natália. O novo desenho institucional do Ministério Público e o processo de judicialização da política. Revista Direito GV, São Paulo, v. 6, n. 2, p. 399-422, jul.dez. 2010.

CARVALHO, Ennani. Em busca da judicialização da política no brasil: apontamentos para uma nova abordagem. Revista de Sociologia e Politica, Curitiba, v. 23, p. 115-126, nov. 2004.

CASTRO, Jorge Abrahão. Nota Técnica - Gasto Social Federal: prioridade macroeconômica no período 1995-2010. IPEA, Brasília, n. 9, set. 2012.

CASTRO, Marcus Faro de. O Supremo Tribunal Federal e a Judicialização da Política. Revista Brasileira de Ciências Sociais, São Paulo, v. 12, n. 34, p. 147-156, 1997.

CHIEFFI, Ana Luiza; BARATA, Rita Barradas. Judicialização da política pública de assistência farmacêutica e equidade. Cadernos de Saúde Pública, Rio de Janeiro, v. 25, n. 8, p. 1839-1849, ago. 2009.

CLAYTON, Cornell W. The supply and demand sides of judicial policy-making (or, why be so positive about the judicialization of politics?). Law and contemporary problems, v. 65, n. 3, Summer, 2002.

CURY, Carlos Roberto J.; AMARAL, Claudia Tavares. O direito à educação básica: análise inicial dos julgamentos do Tribunal de Justiça de Minas Gerais. In: Congresso Ibero Americano de Política e Administração de Educação, IV, Porto, Portugal, 2014. Disponível em: <http:/www.anpae.org.br/IBERO_AMERICANO_IV/GT5/GT5_Comunicacao/CarlosRobertoJ amilCury_GT5_integral.pdf >. Acesso em: 15 de agosto de 2014.

DA ROS, Luciano. Decretos presidenciais no banco dos réus: análise do controle abstrato de constitucionalidade de medidas provisórias pelo Supremo Tribunal Federal no Brasil (1988-2007). 2008. 212f. Dissertação (Mestrado em Ciência Política) - Programa de Pós-Graduação em Ciência Política, Universidade Federal do Rio Grande do Sul, Porto Alegre, 2008. Disponível em: <http://www.lume.ufrgs.br/bitstream/handle/10183/13819/000651720.pdf?sequence $=1>$. Acesso em: 25 out. 2014.

FAGNANI, Eduardo. Análises e propostas - Seguridade Social: a experiência brasileira e o debate internacional. Friedrich Ebert Stiftung, n. 42, p. 1-47, dez. 2011.

FEREJOHN, John. Judicializing politics, politicizing law. Law and contemporary problems, v. 65, n. 3, p. 41-68, summer 2002. 
FERRAZ, Octavio Luiz Motta. Brazil: Health Inequalities, Rights, and Courts: The Social Impact of the "Judicialization of Health' in Litigating Health Rights". In: YAMIN, Alicia Ely; GLOPPEN, Siri (Eds.). Litigating health rights: can courts bring more justice to health. Cambridge: Harvard University Press, 2011a. p. 76 - 102.

. Harming the Poor Through Social Rights Litigation: Lessons from Brazil. Texas Law Revieu, Austin, EUA, v. 89, p. 1643-1668, 2011 b.

FERRAZ, Octávio Luiz Motta; VIEIRA, Fabiola Sulpino. Direito à Saúde, Recursos Escassos e Equidade: Os Riscos da Interpretação Judicial Dominante. Dados, Rio de Janeiro, v. 52, n.1, p. 223-251, mar. 2009.

GANDINI, João A.; BARIONE, Samantha F.; SOUZA, André E. A Judicialização do Direito à Saúde: a obtenção de atendimento médico, medicamentos e insumos terapêuticos por via judicial: critérios e experiências. $\quad$ BDJur, 2007.20 Disponivel <http://www.idisa.org.br/img/File/judicializacao.pdf>. Acesso em: 15 ago. 2014.

IVO, Anete Brito Leal; SILVA, Alessandra Buarque de A. O hiato do direito dentro do direito: os excluídos do BPC. R. Katál, Florianópolis, v. 14, n. 1, p. 32-40, jan.-jun. 2011.

KAPISZEWSKI, Diana; TAYLOR, Matthew. Doing Courts Justice? Studying judicial Politics in Latin America. Perspectives on politics, Cambridge, v. 6, n. 4, p. 741-767, 2008.

KOERNER, Andrei. Ativismo Judicial; Jurisprudência constitucional e política no STF pós-88. Novos estudos, São Paulo, n. 96, p. 69-85, jul. 2013.

MACIEL, Débora Alves; KOERNER, Andrei. Sentidos da judicialização da política: duas análises. Lua Nova, São Paulo, n. 57, p. 113-133, 2002. Disponível em: <http://www.scielo.br/scielo.php?script=sci_arttext\&pid=S0102 64452002000200006\&lng=en\&nrm=iso >. Acesso em: 15 de agosto de 2014.

ONU. Organização das Naçôes Unidas. Assembleia Geral. Declaração Universal dos Direitos Humanos. Brasília, dez. 1948.

NUNES, Rodrigo M. Politics without Insurance: Democratic Competition and Judicial Reform in Brazil. Comparative Politics, New York, v. 42, n. 3, p. 313-331, 2010a.

NUNES, Rodrigo M. Ideal Justice in Latin America: Interests, Ideas, and the Political Origins of Judicial Activism in Brazil and Colombia. Austin: University of Texas, $2010 \mathrm{~b}$.

OLIVEIRA, Eduardo dos Santos de. O Sistema Político Brasileiro hoje: o governo do Supremo Tribunal Federal e a legitimidade democrática. Sociologias, Porto Alegre, v. 15, n. 33, p. 206-246, mai.-ago. 2013.

OLIVEIRA, Fabiana Luci de. Justiça, profissionalismo e política: o STF e o controle da constitucionalidade das leis no Brasil. Rio de Janeiro: FGV, 2011.

PEGORARO, Joana Cristina. A política na corte: uma análise da forma de escolha dos ministros do Supremo Tribunal Federal. 2006. 106f. Dissertação (Mestrado em Ciência Política) - Programa de Pós-Graduação em Ciência Política, Universidade Federal do Rio Grande do Sul, Porto Alegre, 2006.

SANTOS, André Marenco dos; DA ROS, Luciano. Caminhos que levam à Corte: carreiras e padróes de recrutamento dos ministros dos órgãos de cúpula do Poder Judiciário brasileiro (1829-2006). Revista de Sociologia e Política, Curitiba, v.16, n.30, p. 131-149, jun. 2008. SANTOS, Wederson Rufino. Deficiência e democracia: a interpretação do poder judiciário sobre o Benefício de Prestação Continuada. 2009. 107f. Dissertação (Mestrado em Política Social) Programa de Pós-Graduação em Política Social, Universidade de Brasília, Brasília, 2009. 
SILVEIRA, Adriana A. Dragone. Judicialização da educação para a efetivação do direito à educação básica. Jornal de Políticas Educacionais, Curitiba, n. 9, p. 30-40, jan.-jun. 2011.

STF. Supremo Tribunal Federal. Estatísticas do STF. 2014a. Disponível em: <http://www.stf.jus.br/portal/cms/verTexto.asp?servico=estatistica>. Acesso em: 30 nov 2014.

SUPREMO TRIBUNAL FEDERAL. Pesquisa de Jurisprudência. 2014b. Disponível em: <http:/www.stf.jus.br/portal/jurisprudencia/pesquisarJurisprudencia.asp>. Acesso em: 30 nov. 2014.

TATE, C. Neal; VALLINDER, Torbjorn. The global expansion of Judicial Power. New York: New York University Press, 1995.

TAYLOR, Matthew M. Veto and Voice in the Courts: Policy Implications of Institutional Design in the Brazilian Judiciary. Comparative Politics, New York, v. 38, n. 3, p. 337-355, abr. 2006.

VIANNA, Luís Werneck et ai. A judicialização da política e das relaçóes sociais no Brasil. Rio de Janeiro: Revan, 1999.

VIEIRA, Oscar Vilhena. Supremocracia. Revista de Direito GV, São Paulo, v. 4, n. 2, p. 441-464, jul.dez. 2008.

WHITTINGTON, Keith; DEVINS, Neal. Congress and the Constitution. Durham, NC: Duke University Press, 2005.

Texto recebido em 11 de agosto de 2014. Aprovado em 22 de setembro de 2014. 
